\title{
In vivo nutrient digestibility in sheep, and rumen dry matter degradability in cattle fed crop by-product based diets
}

\author{
Safiétou Touré Fall', Maïmouna Cissé1, D. Ditaroh'1, D. Richard², \\ N'Dèye Salane Ndiaye ${ }^{1}$ and B. Diaw ${ }^{1}$ \\ 'ISRA Senegalese Institute of Agricultural Research, \\ National Laboratory of Animal Breeding and Veterinary Research \\ BP 2057 Dakar, Sénégal \\ -CIRAD International Center for Agronomic Research and Development - EMVT, \\ Department of Animal Breeding and Tropical Veterinary Medicine \\ BP 5035 Montpellier; Cedex 01, France
}

(Received 11 September 1997; accepted 25 March 1998)

\begin{abstract}
Nutrient in vivo digestibility in sheep and rumen dry matter degradability in cattle fed cereal straw and concentrate-based diets were determined in two experiments. In Experiment 1, a conventional in vivo balance trial was conducted with six Peul-peul sheep to evaluate apparent digestibility of 3 diets. Diet 1 consisted of $(\mathrm{g} / \mathrm{kg} \mathrm{DM})$ : rice straw 560, molasses 115 , rice bran 180 , peanut cake 130 and mineral supplement 15; diet 2 contained (g/kg DM): millet straw 580, molasses 115 , millet bran 175 , peanut cake 113 and mineral supplement 15 ; diet 3 was a mixture of $(\mathrm{g} / \mathrm{kg} \mathrm{DM})$ peanut hulls 180 and cake 50 , molasses 200 , maize grain 95 , senal $* 200$, cotton seeds 250 and mineral supplement 25 . In Experiment 2, the rumen degradation pattern of the feed ingredients was evaluated using the nylon bag technique in three fistulated Gobra zebu bulls successively fed the same diets.

In vivo dry matter and organic matter digestibility were significantly $(\mathrm{P}<0.05)$ influenced by diet type and particularly cell wall digestion was higher $(\mathrm{P}<0.01)$ in the straw based diets $(1$ and 2$)$ when compared with the mixed feed (diet 3 ). The animal did not influence $(\mathrm{P}<0.05)$ feed degradation profiles which were strongly $(\mathrm{P}<0.001)$ modified by diet and feed type. It was possible to classify different feed types according to their theoretical DM degradability (Dt) in low (Dt $<50 \%$ DM) and medium quality roughages $(50<\mathrm{Dt}>55 \% \mathrm{DM})$ and concentrates $(\mathrm{Dt}>55 \% \mathrm{DM})$. Treatment of straws with molasses $(17 \%)$ significantly $(\mathrm{P}<0.01)$ improved their $\mathrm{DM}$ degradation. The feed average de-
\end{abstract}

* Senal: manufactured concentrate made up of wheat bran, molasses, urea and minerals 
gradation profile was influenced by fibre content, especially lignocellulose $(R=-0.76)$. Feed $D t$ can also be predicted by dry matter disappearance at $24 \mathrm{~h}$ incubation time $(\mathrm{R}=0.90)$ and from individual ingredients in the case of mixed feeds.

KEY WORDS: cereal straws, in vivo digestibility, rumen degradation, cattle, sheep

\section{INTRODUCTION}

Optimization of the rumen function is of major importance for the digestion of diets based on low quality roughages (Sundstøl and Owen, 1984; Galyean and Goetsch, 1993). There are strong relationships between diet composition and digestibility. Rumen microbial ecosystem and activity are influenced by the supplement type and level in the diet which determine the availability of minerals, nitrogen and glucogenic precursors. Special attention is given to cell wall concentration in the ration as it is related to feed efficiency (Van Soest, 1982). Thus, interingredient relationships determine the occurrence of associative effects (Frederiksen, 1973; Kromann, 1973; Sauvant and Giger, 1989; Berge and Dulphy, 1991; Archimede et al., 1996). Rations should then be formulated not only to meet ruminant nutrient requirements but also to stimulate positive interactions among ingredients. The latter interactions may improve the feed value by enhancing feed intake, microbial synthesis and fibre degradation. The extent and rate of feed dry matter intraruminal degradation are valid criteria for assessing the feed value of fibrous feeds for ruminants and the efficiency of the rumen (Ørskov et al., 1980; Preston and Leng, 1987).

The main objective of this study was to assess in vivo dry matter, organic matter, crude protein and fibre digestibility of three diets based on rice straw (diet 1), millet straw (diet 2) and peanut hulls (diet 3 ) and to study rumen efficiency of zebu cattle fed those diets by measuring dry matter degradation of different ingredients using the nylon bag method. The influence of animal, feedstuffs and diet type on the in sacco degradation pattern was studied by comparison of three diets with different levels of concentrates.

\section{MATERIAL AND METHODS}

In vivo digestibility trials - Experiment 1

\section{Animals and diets}

Conventional in vivo balance trials were performed with six young male Peulpeul sheep for evaluation of diet dry matter digestibility. The animals of $25 \mathrm{~kg}$ 
Diets composition and nutritive value, $\%$ of $\mathrm{DM}$

\begin{tabular}{|c|c|c|c|}
\hline \multirow[b]{2}{*}{ Composition } & \multicolumn{3}{|c|}{ Diets } \\
\hline & 1 & 2 & 3 \\
\hline Rice straw & 56 & - & - \\
\hline Rice bran & 18 & - & - \\
\hline Peanut cake & 13 & 11.5 & 5 \\
\hline Peanut hulls & - & - & 18 \\
\hline Cotton seeds & - & - & 25 \\
\hline Millet straw & - & 58 & - \\
\hline Molasses & 11.5 & 11.5 & 20 \\
\hline Millet bran & - & 17.5 & - \\
\hline Maize grain & - & - & 9.5 \\
\hline Senal $^{l}$ & - & - & 20 \\
\hline Mineral mixture & 1.5 & 1.5 & 2.5 \\
\hline Feed unit ${ }^{2} / \mathrm{kg} \mathrm{DM}$ & 0.64 & 0.6 & 0.80 \\
\hline Digestible crude protein, $\mathrm{g} / \mathrm{kgDM}$ & 72 & 67 & 90 \\
\hline Calcium & 5 & 4.5 & 5 \\
\hline Phosphorus & 3 & 3 & 3 \\
\hline
\end{tabular}

' Senal: manufactured concentrate made up of wheat bran $(90 \% \mathrm{DM})+$ molasses $(10 \% \mathrm{DM})$

${ }^{2}$ Feed unit: Net Energy unit (INRA, 1978)

body weight were housed in individual pens equipped for measurement of feed intake and faecal output.

Three diets were studied (Table 1). Two of them contained the test crop residues while the third contained more concentrates and served as a high quality control diet. In straw-based diets, molassed rice straw and molassed millet straw $(17: 63 \mathrm{w} / \mathrm{w})$ were given as a basal diet while the other ingredients were mixed and given as supplement 1 and 2 in diets 1 and 2, respectively. For diet 3 all ingredients were mixed and given as a total compound feed.

\section{Experimental procedures}

Sheep were maintained in individual pens for 15 days of adjustment followed by 6 days of measurement periods. During the latter period, feed offered and refused as well as total faecal output were measured daily and samples were ovendried at $60^{\circ} \mathrm{C}$ for dry matter evaluation. The pooled faecal sample, each feed ingredient, supplement 1 , supplement 2 and mixed diet 3 were collected for chemical analysis. 


\section{Chemical analysis}

Feed ingredients, mixtures and faecal output were analyzed for dry matter, crude protein, phosphorus and calcium (AOAC, 1975) and cell wall components: NDF, ADF and lignin (Goering and Van Soest, 1979).

In sacco degradation trials - Experiment 2

Three young Gobra zebu bulls fitted with rumen cannulae were successively fed diet 1, 2 and 3 (Table 1), each during 15 days of adjustment followed by a 3 day measurement period. Feed ingredients and total rations were sampled, oven dried $\left(60^{\circ} \mathrm{C}\right)$ and ground through a $1 \mathrm{~mm}$ screen for incubation in the rumen. Bags with an internal dimension of $6 \times 11 \mathrm{~cm}$ and made of Blutex nylon material (Tripette et Renaud, France) with $46 \mu \mathrm{m}$ pore size were each filled with $3 \mathrm{~g}$ ground sample and heat sealed. One bag of each sample was withdrawn at 2, 4, 24, 48 and $72 \mathrm{~h}$, washed with running water until clear, then beaten with a stomacher to reduce bacterial contamination (Michalet-Doreau and Ould-Bah, 1989), washed again and oven dried at $60^{\circ} \mathrm{C}$. For each sample six replications were run from two trials with 3 animals.

Calculations and statistical analysis

The significance of differences in dry matter and nutrient digestibilities were assessed by variance analysis using GLM procedures. Animal and diet effects were separated by the Duncan test (SAS, 1988).

Degradation parameters were calculated according to the model of Ørskov and McDonald (1979): $\mathrm{D}=\mathrm{a}+\mathrm{b}\left(1-\mathrm{e}^{-\mathrm{cl}}\right)$;

where $\mathrm{D}$ is the $\mathrm{DM}$ degraded at a given time $\mathrm{t}$; a represents the readily degradable fraction; $b$ is the slowly degraded fraction and $c$ the degradation rate of the $b$ fraction.

Rumen DM degradability (Dt) was calculated according to the equation:

$D t=a+(b c / c+k)$;

in which $\mathrm{k}$ represents the rumen outflow rate of $4 \% \mathrm{~h}^{-1}$ (Lechner-Doll et al., 1992).

To check the existence of lag time (to), the model modification proposed by Dhanoa (1988) was also applied:

$\mathrm{D}=\mathrm{a}+\mathrm{b}\left(1-\mathrm{e}_{-}^{-(\mathrm{ct}-\mathrm{-0})}\right)$ and $\mathrm{Dt}=\mathrm{a}+\left(\mathrm{bc} / \mathrm{c}+\mathrm{ke}^{-\mathrm{kto})}\right)$

To calculate degradation parameters, degradation profiles were fitted to NLIN procedures (Marquardt Methods; SAS, 1988). Analysis of variance using the GLM 
procedure (SAS, 1988) was applied to examine animal, diet and feed effects on degradation parameters. The influence of feed chemical composition on these parameters was examined by regression analysis.

DM degradability (Dt) of supplements 1 and 2 and diet 3 was evaluated from degradability of different ingredients by the following relation:

$$
\mathrm{Dt}=\mathrm{Dt}_{1} \mathrm{~L}_{1}+\mathrm{Dt}_{2} \mathrm{~L}_{2}+\ldots \ldots+\mathrm{Dt}_{\mathrm{x}} \mathrm{L}_{\mathrm{x}}
$$

where $\mathrm{Dt}_{1}=$ degradability for ingredient $1 ; \mathrm{L}_{1}=$ ingredient 1 content in the mixture

$\mathrm{Dt}_{2}=$ degradability for ingredient $2 ; \mathrm{L}_{2}=$ ingredient 2 content in the mixture

$\mathrm{Dt}_{\mathrm{x}}=$ degradability for ingredients $\mathrm{x} ; \mathrm{L}_{\mathrm{x}}=$ ingredient $\mathrm{x}$ content in the mixture

Estimated Dt was then compared to that measured.

\section{RESULTS}

In vivo digestibility - Experiment 1

Chemical composition of feed ingredients and diets. The composition of feed ingredients is given in Table 2. The results are consistent with the usual ranges of tropical feed chemical composition (Kearl, 1982; Richard et al., 1989; Pond et al., 1995). Silica levels were high in cereal straws, peanut hulls and rice bran and also in supplement 1 made in part of rice bran. This is due to soil contamination occurring during processing for agro-industrial by products, or late harvesting in the case of cereal straws.

TABLE 2

Chemical composition of feed ingredients, $\mathrm{g} / \mathrm{kg} \mathrm{DM}$

\begin{tabular}{lccccccc}
\hline Ingredients & Cellulose & Crude protein & NDF & ADF & Si & P & Ca \\
\hline Rice straw & 350 & 41 & 680 & 393 & 152 & 1.1 & 2.8 \\
Millet straw & 380 & 65 & 714 & 453 & 122 & 1.3 & 4.2 \\
Peanut hulls & 348 & 61 & 831 & 708 & 46 & 0.4 & 0.6 \\
Rice bran & 76 & 51 & 655 & 440 & 164 & 3.4 & 0.8 \\
Millet bran & 20 & 139 & 475 & 14 & 65 & 5.1 & 1.1 \\
Senal & 123 & 228 & 527 & 177 & 5.9 & 3.8 & 15.0 \\
Peanut cake & 50 & 485 & 376 & 202 & 8.6 & 4.6 & 1.2 \\
Cotton seeds & 241 & 240 & 466 & 327 & 3.9 & 5.0 & 1.3 \\
Supplement 1 & 218 & 175 & 674 & 331 & 122 & 4.5 & 4.1 \\
Supplement 2 & 73 & 232 & 795 & 121 & 53 & 5.5 & 7.3 \\
Maize grain & 19 & 88 & 678 & 47 & 5.5 & 1.3 & 0.9 \\
Diet 3 & 184 & 162 & 607 & 290 & 23 & 4.9 & 0.6 \\
Molasses & 0 & 6 & - & - & - & 0.7 & 7.3 \\
\hline
\end{tabular}


TABLE 3

Average chemical composition of feed consumed

\begin{tabular}{lcccccc}
\hline Diets & DM intake & OM & CP & NDF & ADF & ADL \\
\cline { 3 - 6 } & $\mathrm{g} / \mathrm{kg} \mathrm{BW}^{0.75}$ & & & $\% \mathrm{DM}$ & \\
\hline 1 & 64 & 81.6 & 11.6 & 55.3 & 33.3 & 6.4 \\
2 & 59 & 81.0 & 11.2 & 42.3 & 24.6 & 5.5 \\
3 & 88 & 88.3 & 16.0 & 36.6 & 26.4 & 10.5 \\
\hline
\end{tabular}

Average chemical composition of total diet intake is shown in Table 3. OM content was similar from one diet to another while ration 2 was higher in $\mathrm{CP}$ compared with cereal by-product based diets which had a higher fibre concentration.

TABLE 4

In vivo digestibility of nutrients in tested rations, \% of DM

\begin{tabular}{lcccccc}
\hline Diets & DM $^{*}$ & OM $^{*}$ & CP* $^{*}$ & NDF** $^{*}$ & ADF** $^{*}$ & ADL $^{* *}$ \\
\hline 1 & $52.0^{\mathrm{a}}$ & $58.7^{\mathrm{a}}$ & $68.1^{\mathrm{a}}$ & $51.9^{\mathrm{a}}$ & $49.5^{\mathrm{a}}$ & $12.1^{\mathrm{a}}$ \\
2 & $56.0^{\mathrm{b}}$ & $63.6^{\mathrm{b}}$ & $57.3^{\mathrm{b}}$ & $52.9^{\mathrm{a}}$ & $53.5^{\mathrm{a}}$ & $17.3^{\mathrm{a}}$ \\
3 & $56.9^{\mathrm{b}}$ & $57.6^{\mathrm{a}}$ & $69.8^{\mathrm{a}}$ & $24.6^{\mathrm{b}}$ & $17.2^{\mathrm{b}}$ & $5.5^{\mathrm{b}}$ \\
\hline
\end{tabular}

means with different superscripts are significantly different ; ${ }^{*} \mathrm{P}<0.05 ;{ }^{*} \mathrm{P}<0.01$

In vivo digestibility of diets. Table 4 shows the in vivo apparent digestibility of tested diets. Variations between animals were not significant $(\mathrm{P}<0.05)$. Average dry matter (DMD), organic matter (OMD) and crude protein digestibility (CPD) were significantly influenced by the diet type $(\mathrm{P}<0.05)$. Those differences were more pronounced in cell wall components which were better $(\mathrm{P}<0.01)$ digested in straw based rations. NDF digestibility (NDFD) averaged $52 \%$ in diets 1 and 2 against $25 \% \mathrm{DM}$ only in diet 3 . The same tendency was observed in ADF and lignin digestibility. Thus, the low fibre content in diet 3 , appeared to have a negative effect on cell wall digestibility.

In sacco degradability - Experiment 2

DM degradation profiles of tested feeds are presented in Table 5 and Figures 1, 2 and 3. Table 6 shows calculated degradation parameters. The two applied models gave similar results in concentrate feeds while degradation parameters differed in low quality roughage. With the Dhanoa model it was possible to select the slowly degraded feedstuffs with a lag time varying from 3 to $4.9 \mathrm{~h}$ in cereal straws.

Degradation kinetics varied within a wide range from rice straw $(\mathrm{dt}=47 \% \mathrm{DM})$ to Senal $(\mathrm{dt}=70 \% \mathrm{DM})$. Differences among feeds were highly significant 
TABLE 5

Dry matter degradability of feeds (\% DM): influence of the diet type

\begin{tabular}{llll}
\hline & \multicolumn{3}{c}{ Diet } \\
\cline { 2 - 4 } Ingredients & 1 & 2 & 3 \\
\hline Rice straw & 44 & 50 & 47.4 \\
Molassed rice straw & 52 & 52.1 & 52.1 \\
Millet straw & 49.5 & 49.6 & 51.4 \\
Molassed millet straw & 52.1 & 52.1 & 52.1 \\
Peanut hulls & 50.4 & 50.4 & 49.6 \\
Rice bran & 50.3 & & \\
Millet bran & 51.4 & & \\
Senal & 69.8 & 68.8 & 69.7 \\
Peanut cake & 68.5 & & \\
Cotton seeds & 54.7 & 55.8 & 53.8 \\
Supplement 1 & 52.4 & & \\
Supplement 2 & 61.8 & & \\
Maize grain & 68.9 & & \\
Diet 3 & 65.5 & & \\
\hline
\end{tabular}
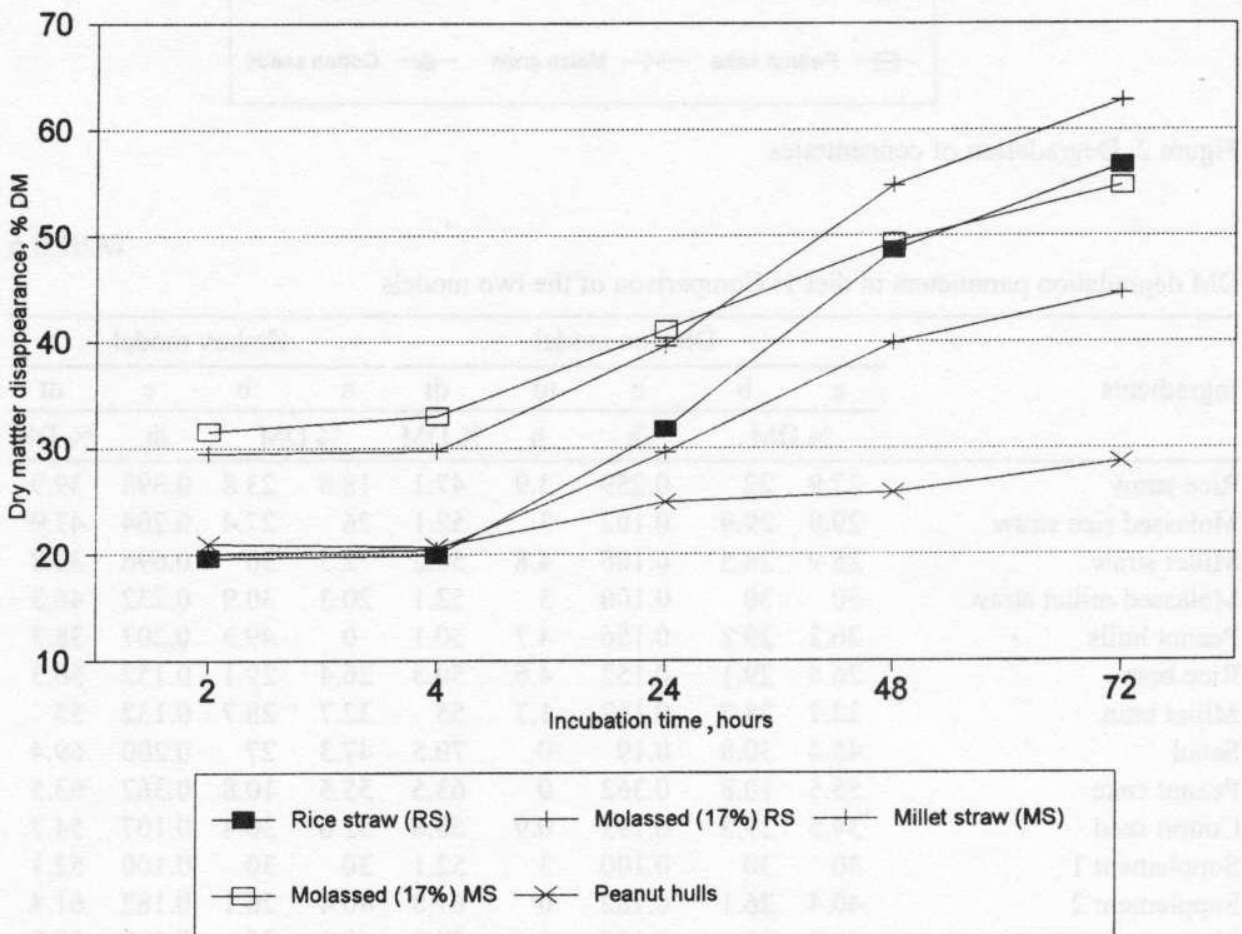

Figure 1. Degradation of basal diets 


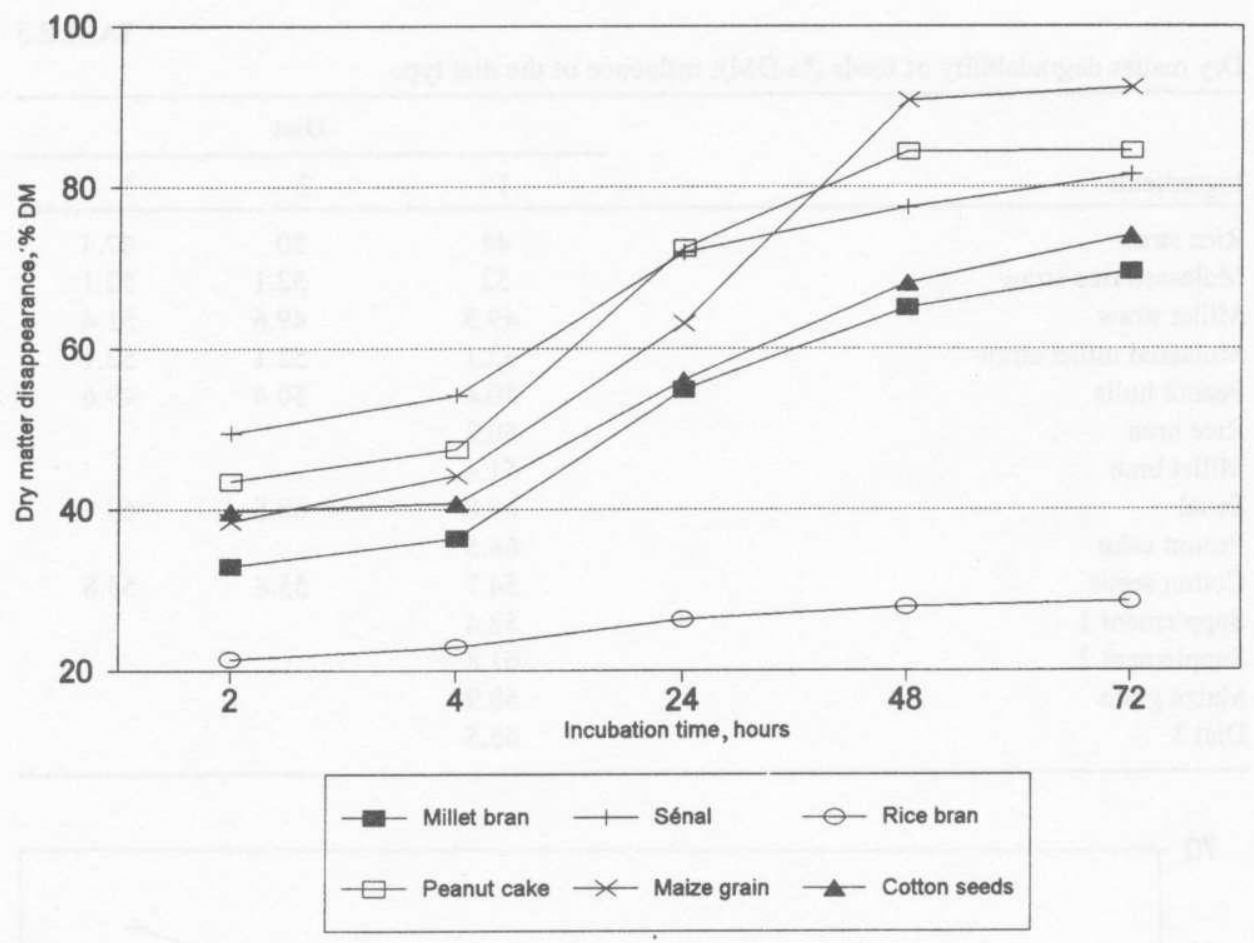

Figure 2. Degradation of concentrates

TABLE 6

DM degradation parameters in diet 1: Comparison of the two models

\begin{tabular}{|c|c|c|c|c|c|c|c|c|c|}
\hline \multirow{3}{*}{ Ingredients } & \multicolumn{5}{|c|}{ Dhanoa model } & \multicolumn{4}{|c|}{ Ørskov model } \\
\hline & $\mathrm{a}$ & b & c & to & $\mathrm{dt}$ & $\mathrm{a}$ & $\mathrm{b}$ & c & $\mathrm{dt}$ \\
\hline & \multicolumn{2}{|c|}{$\% \mathrm{DM}$} & $/ \mathrm{h}$ & $\mathrm{h}$ & $\% \mathrm{DM}$ & \multicolumn{2}{|c|}{$\% \mathrm{DM}$} & $\mathrm{h}$ & $\% \mathrm{DM}$ \\
\hline Rice straw & 27.9 & 22 & 0.259 & 3.9 & 47.1 & 18.8 & 23.8 & 0.398 & 39.9 \\
\hline Molassed rice straw & 29.9 & 29.9 & 0.102 & 3 & 52.1 & 26 & 27.4 & 0.204 & 47.9 \\
\hline Millet straw & 25.9 & 28.5 & 0.186 & 4.8 & 50.2 & 2.5 & 30 & 0.696 & 30.8 \\
\hline Molassed millet straw & 30 & 30 & 0.100 & 3 & 52.1 & 20.3 & 30.9 & 0.232 & 46.3 \\
\hline Peanut hulls & 26.2 & 29.2 & 0.156 & 4.7 & 50.1 & 0 & 49.3 & 0.207 & 38.3 \\
\hline Rice bran & 26.4 & 29.1 & 0.152 & 4.6 & 50.3 & 26.4 & 29.1 & 0.152 & 50.3 \\
\hline Millet bran & 32.7 & 28.7 & 0.132 & 1.7 & 55 & 32.7 & 28.7 & 0.132 & 55 \\
\hline Senal & 45.4 & 30.8 & 0.19 & 0 & 70.5 & 47.3 & 27 & 0.200 & 69.4 \\
\hline Peanut cake & 55.5 & 10.8 & 0.362 & 0 & 63.5 & 55.5 & 10.8 & 0.362 & 63.5 \\
\hline Cotton seed & 34.5 & 29.3 & 0.193 & 0.9 & 58.8 & 32.6 & 30.4 & 0.107 & 54.7 \\
\hline Supplement 1 & 30 & 30 & 0.100 & 3 & 52.1 & 30 & 30 & 0.100 & 52.1 \\
\hline Supplement 2 & 40.4 & 26.1 & 0.182 & 0 & 61.8 & 40.4 & 26.1 & 0.182 & 61.8 \\
\hline Maize grain & 40.9 & 25 & 0.107 & 0 & 59.2 & 40.9 & 25 & 0.107 & 59.2 \\
\hline Diet 3 & 35.6 & 38.8 & 0.168 & 0.2 & 66.9 & 37.7 & 31.9 & 0.276 & 65.5 \\
\hline
\end{tabular}




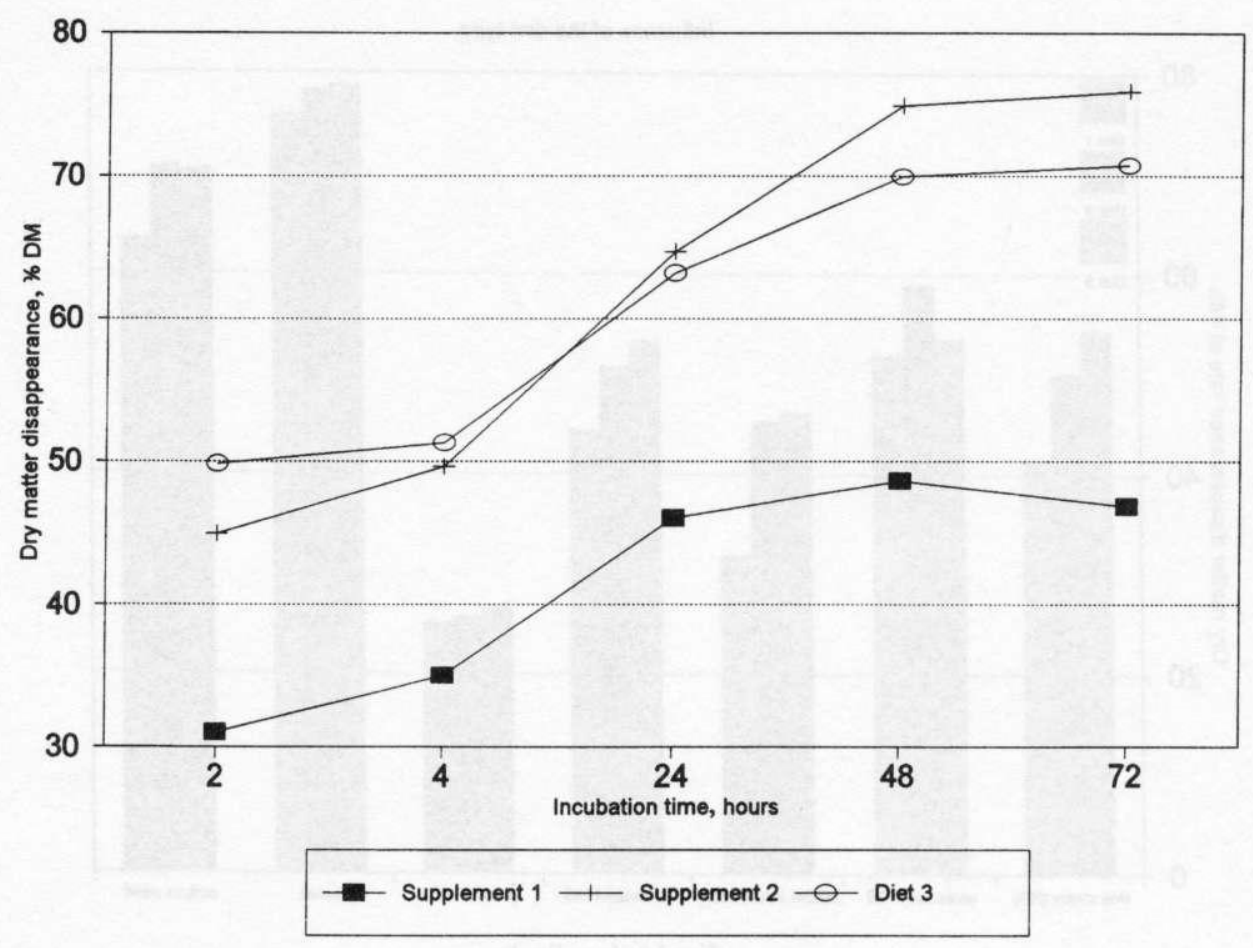

Figure 3. Degradation of feed mixtures

$(\mathrm{P}<0.0001)$. Three groups could be distinguished. Low quality feeds like straws fed alone, peanut hulls and rice bran $(\mathrm{dt}<50 \% \mathrm{DM})$, medium quality forage like molassed cereal straws $(50<\mathrm{Dt}<55 \% \mathrm{DM})$ and concentrates $(\mathrm{Dt}>55 \% \mathrm{DM})$. There was a significant $(\mathrm{P}<0.01)$ beneficial effect when cereal straws where treated with molasses.

Differences in feed degradability were related to fibre content. ADF and crude fibre (CF) were the best predictors of DM degradability.
$\mathrm{Dt}=66.8-0.046 \mathrm{ADF}$
$\mathrm{R}=0.76$
$\mathrm{P}<0.001$
$\mathrm{SE}=7.1 \quad \mathrm{~N}=14$
$\mathrm{Dt}=63.7-0.057 \mathrm{CF}$
$\mathrm{R}=0.76$
$\mathrm{P}<0.001$
$\mathrm{SE}=7.1 \quad \mathrm{~N}=14$

Among concentrate feeds, whole cotton seeds which have the highest fibre content, were less degraded than Senal; the same for millet straw among the fibrous feeds. Silica $(R=-0.65)$ and $\operatorname{NDF}(R=-0.57)$ may also play a negative role in $\mathrm{DM}$ degradation profile.

The animal did not influence the degradation profiles of different diets significantly $(\mathrm{P}<0.05)$ while diet type was a major variation factor $(\mathrm{P}<0.001)$. Compared with a high concentrate diet, straw based diets (1 and 2$)$ offered higher dry matter degradability at $48 \mathrm{~h}$ incubation time (Figure 4 ). The applied calculation model 


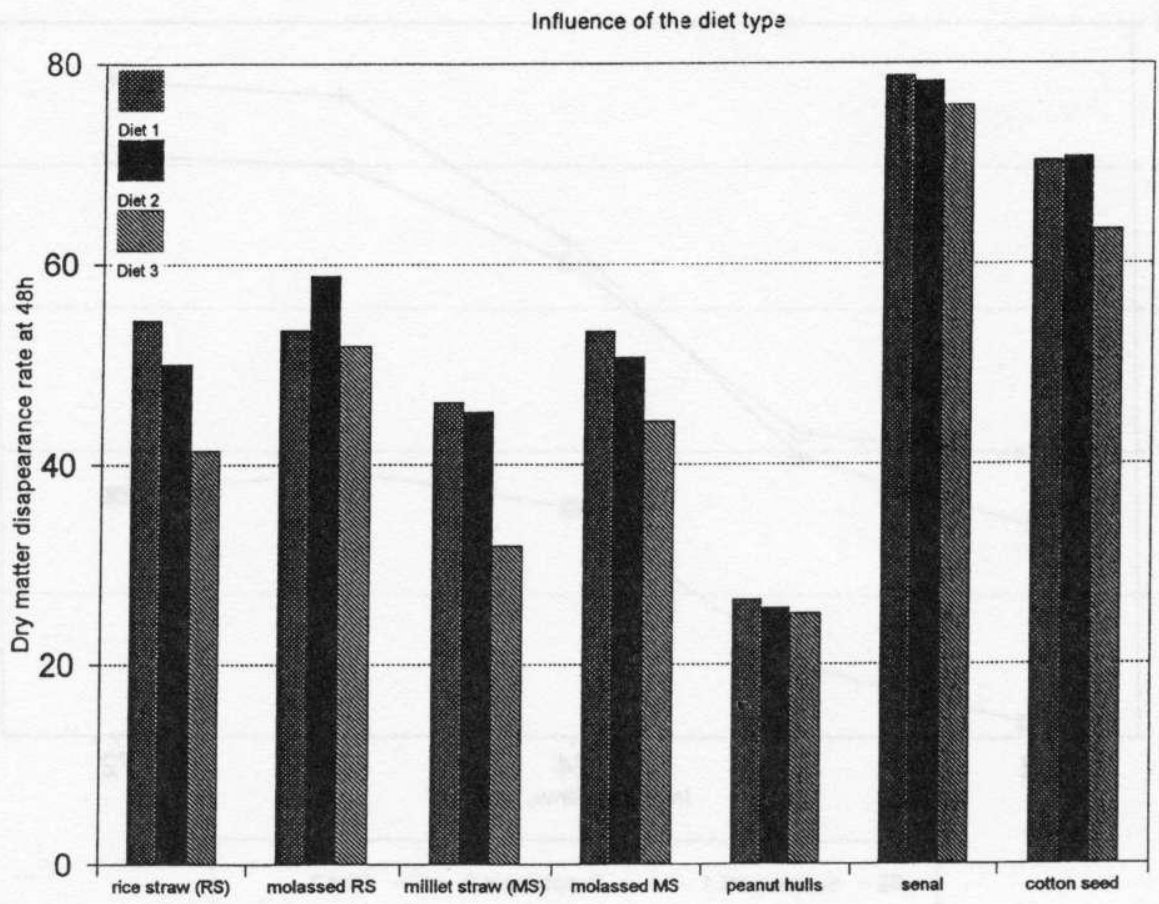

Figure 4. Degradation of feedstuffs

Feed indgredients

influences the extent of between-diet variation; in the Ørskov model strong variation profiles were observed among diets while those differences were not important when the Dhanoa model was used (Table 5).

Measured and calculated Dt values were closely similar for Supplement 2. A difference of 5 points was observed in supplement 1 and diet 3 (Table 7).

Dt could also be predicted from dry matter disappearance at $24 \mathrm{~h}$ incubation time (Deg24h)

$$
\mathrm{Dt}=24.4+0.563 * \operatorname{Deg} 24 \mathrm{~h} \quad \mathrm{R}=0.90 \quad \mathrm{P}<0.001 \mathrm{SE}=5.0 \quad \mathrm{~N}=14
$$

In vivo digestibility (DMD) was close to dry matter degradability (Dt): 56.9 vs $54.9 \% \mathrm{DM}$ in diet 3 .

Estimation of mixed feeds Dt (\% DM) from individual ingredients

\begin{tabular}{lccc}
\hline & Supplement 1 & Supplement 2 & Diet 3 \\
\hline Calculated & 57.6 & 60.4 & 71.5 \\
Measured & 52.1 & 61.8 & 66.2 \\
Difference & -5.5 & -1.4 & -5.3 \\
\hline
\end{tabular}




\section{DISCUSSION}

OMD was comparable to our previous results (Fall et al., 1989; Richard et al., 1989 ) in the rice straw based diet while it was superior to the millet straw based one. That may be due to better forage quality with good leaf preservation. The concentrate mixture (diet 3) had low DM and OM digestibility because of low cell wall digestion. The NDF content of that diet was $61 \%$ DM and only 25,17 and $5 \%$ of NDF, ADF and lignin was digested, respectively. A lower retention time because of its fine texture might also depress total OMD of the concentrate mixture.

DM degradation profiles were quite different from one feedstuff to another. In general, the feed classification made on the Dt basis gave the usual ranking of feedstuffs except for rice bran which, expected to be a concentrate, was classified among the lowest quality feeds. This may be due to soil contamination of rice bran and peanut hulls during processing as indicated by high NDF and silica contents (Table 2).

Rice and millet straw degradation profiles $(\mathrm{a}+\mathrm{b}=30$ to $60 \% \mathrm{DM})$ were close to those of $\varnothing$ rskov (1988) for different wheat straw varieties. They differed from those reported for Mediterranean countries in which the $a+b$ value varied from 60 in triticale to $70 \% \mathrm{DM}$ in wheat straw (Chermiti et al., 1996). They were also lower than the barley straw DM degradability $(a+b=66 \% \mathrm{DM})$ described by Bhargava et al. (1986), but higher than that reported by Hvelplund (1989) $(a+b=24)$. These differences can be explained by drought stresses and poor harvesting conditions leading consequently to large leaf losses, soil contamination and digestibility depression. The heterogeneity of straws is well known to depend on plant species and variety, year, harvesting period and methods (Bhargava et al., 1988; Cappers et al., 1988; Ørskov, 1988).

As expected, the Dt values of concentrates were high in general except for that of rice bran which was of low quality with high NDF and silica contents (Table 2).

Feed degradability was well predicted by fibre content and strong relationships between $\mathrm{ADF}$ and $\mathrm{Dt}(\mathrm{R}=-0.76)$ were found. The negative effect of lignocellulose (ADF) on feed digestibility in general, and particularly in low quality roughages is well known (Van Soest, 1982; Akin et al., 1990). So processing fibrous feeds and supplementation strategies should be directed to improve cell wall digestion.

Having in mind that nylon bag studies are not always easy to carry out, estimation of feed degradability from chemical composition and ingredient proportions in the diet could help simplify the method. Estimates of the mixed feed Dt from the Dt of individual ingredients were in agreement with the findings of Stallings et al. (1991) regarding the protein degradation profile of diets containing barley silages. That method can be a useful tool for estimating the degradability of mixed feed diets. 
Measurement of in vivo DMD of three diets based on crop by-products available in Senegal showed comparable value regarding DM and OM digestibility between millet and rice straw based diets compared to a high concentrate mixture. Cereal straw based diets showed a higher tendency to digest fibre.

In vivo observations were confirmed by in sacco results which showed significant $(\mathrm{P}<0.001)$ influence of the ration type on DM degradation profiles for the 14 incubated feeds. In general, better fibre digestion in straw-based diets compared with high concentrate diets was observed.

The diet influence in the rumen DM degradation profile demonstrates the occurrence of associative effects. The different diet components, the fibrous feeds/concentrates ratio in particular, affect energy digestion. Such digestive interactions between feeds has been widely reported (Galyean and Goetsch, 1993).

Interrelationships between ruminal ecosystems and straw digestion have been reviewed in detail by Durand (1989) and Galyean and Goetsch (1993). Diets 1 and 2 were characterized by high straw levels (concentrate/straw ratio $=43 / 57$ ) and low readily fermentable carbohydrate content. These types of feeds have a high buffering capacity probably linked to greater salivary secretion and higher rumen residence time. The rumen ecosystem stimulates cellulolytic microorganisms which degrade fibre (Chamberlain and Choung, 1995). In contrast, diet 3 had a high concentrate proportion ( $82 \%$ of the diet) with a predominance of readily fermentable carbohydrate through molasses and maize grains. This diet may develop rumen microbial population that degrades starch and simple sugars rather than low quality fibres. The two diet types may also be differentiated by texture. Straw based diets were coarser than that based mainly on concentrates; this may stimulate intake and rumen outflow rate and thus decrease DM degradability. This is in agreement with $\varnothing$ rskov (1983) and Preston and Leng (1987) who reported better degradability of high fibre content feedstuffs in straw based diets compared with compounded concentrate ones. The latter are rich in soluble and readily degraded carbohydrates which are preferred by microorganisms to complex sugars like cellulose or hemicellulose to satisfy their energy requirements. In addition, concentrate diets give lower rumen $\mathrm{pH}$ and hence inhibit fibre digestion.

\section{CONCLUSIONS}

Marked influence of diet type on the dry matter digestion profile of feed ingredients demonstrates the occurrence of negative interactions when the concentrate proportion is greater than the level of low quality forages. The latter should be restricted for optimal stimulation of cellulolytic bacteria. Therefore, utilization of expensive concentrates should be minimal to avoid low rumen $\mathrm{pH}$ and related fibre digestion inhibition and ensure proper utilization of fibrous feeds. 


\section{ACKNOWLEDGEMENTS}

This work was funded by the Canadian International Development Research Center (IDRC), project No 3P 90 0200. Authors are indebted to P. Cheeke and A. Skreder for helpful comments.

\section{REFERENCES}

Akin D. E., Ljungdahl L. G., Wilson J. R., Harris P. J. (Editors), 1990. Microbial and Plant Opportunities to Improve Lignocellulose Utilization by Ruminants. Proceedings Workshop Athens, Georgia. Elsevier, The Netherlands, pp. 428

Archimede H., Sauvant D., Hervieu J., Ternois F., Poncet C., 1996. Effects of the nature of roughage and concentrate and their proportion on ruminal characteristics of non lactating goats, consequence on digestive interactions. Anim. Feed Sci. Technol. 58, 267-282

Association of Official Agricultural Chemist, AOAC, 1975. Official Methods of Analysis, 12th Edition. AOAC. Washington, DC

Berge P., Dulphy J.P., 1991. Etude des interactions entre fourrage et aliment concentré chez le mouton. II. Facteur de variation de la digestibilité. Ann. Zootech. 40, 227-246

Bhargava P. K., Ørskov E. R., Walli T. K., 1988. Rumen degradation of straw. Selection and degradation of morphological components of barley straw by sheep. Anim. Prod. 47, 105-110

Cappers B. S., Thomson E. F., Herbert F., 1988. Genetic variations in the feeding value of barley and wheat straw. In: J. D. Reed, P. J. H. Neate, B. S. S. Cappers (Editors). Plant breeding and the nutritive value of crop residues. ILCA Addis Abeba (Ethiopia), pp. 177-193

Chamberlain D. G., Choung J. J., 1995. The importance of rate of ruminal fermentation of energy sources in diets for dairy cows. In: P. C. Garnsworthy D. J. A. Cole (Editors). Recent advances in animal nutrition. Nottingham University Press, pp. 3-27

Chermiti A., Nefzaoui A., Teller E., Vanbelle M., Ferchichi H., Rokbani N., 1996. Prediction of the voluntary intake of low quality roughages by sheep from chemical composition and ruminal degradation characteristics. Anim. Sci. 62, 57-62

Chesson A., Ørskov E. R., 1984. Microbial degradation in the digestive tract. In: F. Sundstol E. Owen (Editors). Straw and other fibrous by product as animal feed. Elsevier Press, Amsterdam, pp. 305- 339

Church D. C., 1983. Rumen microbiology. In: Digestive physiology and nutrition of ruminants. Vol. 14 Edition. O. \& B.Books Inc., Corvallis, OR, pp. $174-226$

Dhanoa M.S.; 1988. Research note on the analysis of dacron bag data for low degradability feeds. Grass Forage Sci. 43, 441-444

Durand M., 1989. Conditions for optimizing cellulolytic activity in the rumen. In: M. Chenost, P. Reiniger (Editors). Evaluation of straws in ruminant feeding. Elsevier Applied Science, London, New York, pp. 3-18

Fall S.T., Guerin H., Sall C. and MBaye N., 1989. Cereal straws in the feeding systems of ruminants in Senegal. In: B. Dzowela, A.N. Said (Editors). Overcoming constraints to the efficient utilization of agricultural by-products as animal feed. ILCA Addis Abeba (Ethiopia), pp. 173-189

Frederiksen H.J., 1973. Method studies relating to digestibility trials with ruminants. Acta Agric. Scand. $23,17-32$ 
Galyean M. L., Goetsch A. L., 1993. Utilization of forage fibres by ruminants. In H. G. Jung, D. R. Buxton, R. D. Hatfield, J. Ralph (Editors). Forage cell wall structure and digestibility. Proceedings of International Symposium on Forage Cell Wall Structure and Digestibility. Madison, Wisconsin, pp. 33-71

Hvelplund T., 1989. Protein evaluation of treated straws. In: M. Chenost, P. Reiniger (Editors). Evaluation of straws in ruminant feeding. Elsevier Applied Science, London, New York, pp. 66-74

Kearl L.C., 1982. Nutrient Requirements of Ruminants in the Developing Countries. International Feedstuff Institute, Publ. Utah Agriculture Experiment Station. Utah State University, Logan, UT, pp. 381

Kromann R.P., 1973. The energy value of feeds as influenced by associative effects. Proceedings of 1st International Crop Drying Congress, Oxford, pp. 81-98

Lechner-Doll M., Rutagwenda T., Schwartz H.J., Schultka W., and Engelhardt W.V., 1990. Seasonal changes of ingesta mean retention time and forestomach fluid volume in indigenous camel, cattle, sheep and goats grazing a thornbush savannah pasture in Kenya. J. Agric. Sci., Camb. $115,409-420$

Michalet-Doreau B., Ould-Bah M.Y., 1989. Estimation of the extend of bacterial contamination in bag residues and it's influence on in sacco measurements of forage nitrogen degradation in the rumen. Proceedings of the $16^{\text {th }}$ International Grassland Congress, pp. $909-910$

Ørskov E.R., 1983. Supplementation of low quality roughage diet for optimal microbial and host animal nutrition. In: Utilisation of low quality roughages diet with special reference to developing countries. Proceedings of a Workshop on applied research held in Alexandria (Egypt), pp. 84-87

Ørskov E. R., 1988. Consistency of differences in nutritive value of straws from different varieties in different seasons. In: J. D. Reed, B. S. Cappers, P. J. H. Neate (Editors). Plant breeding and the nutritive value of crop residues. ILCA Addis Abeba (Ethiopia), pp. 163-172

Ørskov E.R., Deb Howell F.D., Mould F., 1980. The use of nylon bag technique for the evaluation of feedstuffs. Trop. Anim. Prod. 5, 195-213

Ørskov E.R., McDonald L., 1979. The estimation of protein degradability in the rumen from incubation meseasurements weighted accirding to rate of passage. J. Agric. Sci., Camb. 92, 499-503

Pond W. G., Church D. C., Pond K. R., 1995. Basic Animal Nutrition and Feeding. 4th Edition. John Wiley and Sons. New York, pp. 615

Preston T.R., Leng R.A., 1987. Matching Ruminant Production Systems with Available Resources in the Tropics and Subtropics. Penambul Books Armidale, pp. 245

Richard D., Guérin H., Fall S.T., 1989. Feeds in the dry tropics. In: R. Jarrige (Editor). Ruminants nutrition. Recommended allowance and feed tables. INRA (France) pp. 345-357

SAS, 1988. SAS user guide: Statistics. Cary, NC SAS Institute Inc.

Sundstøl F., Owen E. (Editors), 1984. Straw and Other Fibrous By-Products as Animal Feed. Elsevier Press, Amsterdam, pp. $305-413$

Sauvant D., Giger S., 1989. Straw digestibility calculation and digestive interactions. In: M. Chenost, P. Reiniger (Editors). Evaluation of straws in ruminant feeding. Elsevier Applical Science, Amsterdam pp. 47-61

Stallings C.C., Acosta Y.M., Polan C.E., 1991. Predicting diet protein degradability from individual ingredient estimations in diets containing barley silages. J. Dairy Sci. 74, 3486-3491

Van Soest P.J., 1982. Nutritional Ecology of the Ruminant. O. \& B. BOOKS, Inc. Corvallis, OR, pp. 374 


\section{STRESZCZENIE}

Strawność składników pokarmowych przez owce i rozklad suchej masy w żwaczu bydla dawek zawierających uboczne produkty roślinne

W dwóch doświadczeniach oznaczono na owcach strawność składników pokarmowych oraz rozkład suchej masy w żwaczu bydła dawek zawierających słomę zbożową i paszę treściwą. W doświadczeniu 1, przeprowadzonym na sześciu owcach Peul-peul, oznaczono strawność pozorną 3 dawek. Dawka 1 składała się z (g/kg s.m) słomy ryżowej 580, melasy 115 , otrąb ryżowych 180 , makuchu arachidowego 130 i dodatku mineralnego 15 ; dawka 2: słoma z prosa 580 , melasa 115 , otręby z prosa 175 , makuch arachidowy 113 i mieszanka mineralna 15 ; dawka 3 : mieszanka łusek 180 i makuchu arachidowego 50 , melasa 200 , ziarno kukurydzy 95 , senal 200 , nasiona bawełny 250 i dodatck mineralny 25 . W doświadczeniu 2 oznaczono rozkład s.m., stosując metodę woreczków nylonowych, na 3 buchajkach Gobra zebu, otrzymujących te same pasze.

Na strawność s.m. i substancji organicznej, oznaczonej in vivo, istotnie wpłynął $(\mathrm{P}<0,05)$ rodzaj skarmianej dawki; strawność błon komórkowych dawek zawierających słomę (1 i 2) była większa $(\mathrm{P}<0,01)$ niż dawki 3. Stopień rozkładu s.m. zależał od rodzaju dawki i typu paszy $(\mathrm{P}<0,001)$. W oparciu o te wyniki autorzy proponują podział różnych rodzajów pasz na podstawie ich teoretycznego rozkładu (Dt) s.m.: nisko (Dt<50\% s.m.) i średniej jakości pasze objçtościowe $(50<\mathrm{Dt}>55 \%$ s.m.) i pasze treściwe (Dt $>55 \%$ s.m.). Traktowanie słomy melasą (dodatek $17 \%$ melasy do słomy) istotnie $(\mathrm{P}<0,01)$ zwiększało jej rozkład. Stopień rozkładu s.m. paszy zależał od zawartości włókna, a szczególnie lignocelulozy $(R=-0,76)$. Dt paszy może być także oszacowane na podstawie ubytku s.m. w czasie 24 godzinnej inkubacji $(\mathrm{R}=0,90)$ lub w przypadku mieszanek paszowych ubytku s.m. poszczególnych składników dawki. 